\title{
CERTAIN MILESTONES IN THE HISTORY OF LUTHERAN CONGREGATIONS OF THE GERMAN IMMIGRANTS TO THE PHILIPPI FLATS: 1877-2007
}

\author{
Lizette Rabe \\ Department of Journalism, Stellenbosch University, Stellenbosch 7600
}

\section{Sekere mylpale in die geskiedenis van die gemeentes van die Duitse immigrante na Philippi-Vlakte: 1877-2007}

Die jaar 2007 is die 130ste gedenkjaar van die koms van die sogenaamde tweede golf van Duitse immigrante na die Wes-Kaap, spesifiek na die Kaapse Vlakte. Nuwejaarsdag 2007 was ook die 120ste herdenking van die onafhanklikheid van die Wynbergse Lutherse gemeente. Dit is ook die jaar waarin hierdie oudste, en tweede, van die oorspronklike drie Lutherse gemeentes wat die gemeenskap bedien het, sal ophou om as onafhanklike gemeente te funksioneer en in 'n sogenaamde 'gemeenteverband' met die laaste oorblywende gemeente sal tree. Sowel die kerkgebou van die Philippigemeente as die kerkgebou van die gemeente wat eerste gesluit het, dié van NeuEisleben, is boonop vanjaar 110 jaar gelede gebou. Hierdie artikel gee 'n oorsig oor die geskiedenis van die gemeenskap in die lig van spesifieke mylpale voor en sedert 1877. Dit boekstaaf verder die gedagtes van 'n paar afstammelinge wat direk deur die opskorting van die oudste gemeente as onafhanklike gemeente geraak word.

Sleutelterme: Duitse immigrasie, koloniale regering, landbou, Lutherse Kerk.

The year 2007 marks the $130^{\text {th }}$ commemoration of the arrival of the so-called Second Wave of German immigrants to the Western Cape, specifically to the Cape Flats, while New Year's Day 2007 commemorated the $120^{\text {th }}$ year of independence of the Wynberg Lutheran congregation. Yet, it is also the year in which this, the oldest, and the second of the original three Lutheran congregations that have served this community, will cease to function as an independent congregation and will become a so-called parish of the last remaining congregation. The church building of this last remaining Philippi congregation, as well as the church of the first congregation that ceased to exist, that of Neu-Eisleben, was built 110 years ago, in 1897. This article gives an overview of the history of this community, indicating certain milestones before and since 1877, and records the thoughts of a couple of those descendants who are 
touched directly by the prorogation at the beginning of the $21^{\text {st }}$ century of the independent existence of the oldest congregation.

Key words: agriculture, colonial government, German immigrants, Lutheran Church.

\section{Introduction}

Descendants of German immigrants to the Western Cape, specifically to what had then been called Claremont Flats and Wynberg Flats since the middle of the 1850s to 1883, comprise the community at Philippi Flats, the agricultural section of the larger geographical area of the Cape Flats, that specialises in the cultivation of vegetables for the bigger Cape metropolis.

Those descendants who still belong to the Evangelical Lutheran Church are mostly members of the two existing Lutheran churches, namely the Philippi Evangelical Lutheran Church (also known as the Zionskirche) and the St Johanniskirche in Wynberg, which in July 2007 will cease to exist as an independent congregation.

Members of the congregation of especially the Philippi church are mostly the descendants of German settlers who came in three "waves" to the Western Cape over a period of 25 years from 1858 to 1883 . This immigration was part of the "Völkerewanderung" (migration of the nations), the mighty socio-cultural phenomenon of the nineteenth century when an estimated 5 million Germans from the various German states emigrated between 1820 and 1890 to parts of the "New World". Those who migrated to the southern tip of Africa, and who ended up on the Cape Flats, were the "Godeffroy Settlers", ${ }^{2}$ comprising the First Wave, the Second Wave, arriving from 1877 to 1878, and the Third Wave in 1883 .

The year 2007 therefore commemorates the arrival of the Second Wave immigrants from 1877/78, and it marks the year in which the oldest (founded in 1861) ${ }^{3}$ of the original three Lutheran congregations that have served the community, will cease to function as an independent congregation and enter into a cooperative agreement with the last independent congregation. It is also the second of these three congregations that will cease to exist - in the last case as an independent congregation, unlike the Neu-Eisleben congregation that was dissolved. The Wynberg

\footnotetext{
E.L.G. Schnell, For men must work (Grahamstown, 1954), p. 159.

L. Rabe, 'n Kultuurhistoriese studie van die Duitse nedersetting Philippi op die Kaapse Vlakte (D.Phil.-proefskrif, Universiteit van Stellenbosch, 1994).

H. Ludewig, Geschichte der Deutschen Evangelisch-Lutherischen St. Johannis-Gemeinde zu Wynberg bei Kapstadt (Braunschweig, 1911), p. 13.
} 
congregation will become a so-called parish in terms of a cooperative agreement as part of the last remaining congregation, that of Philippi (founded in 1896). ${ }^{4}$

The members of the first congregation that had to close, Neu-Eisleben, joined the Philippi congregation after the Dunes, the agricultural area in Philippi where they lived, became depopulated in the 1980s due to the informal settlements that took root there. Today the area consists mostly of the township of Kayelitsha. ${ }^{5}$ It is ironical that the year 2007 marks the fact that the St Johannis congregation will become a parish of the Philippi congregation, as its existence in the 1800s led directly to the settlement of German immigrants on the Philippi Flats.

It was thanks to the existence of this congregation in the 1860s that German settlers of the First Wave settled in the vicinity after they had worked themselves free from their original contracts. This led to the decision by the Cape colonial government to encourage more German immigration to this specific area, and therefore led directly to the arrival of the immigrants of the Second and Third Waves.

This article reflects on the history of the community, the settlers that were instrumental in the growth of the St Johannis congregation, and the eventual demise of this, the oldest congregation. The article, therefore, also seeks to record some thoughts of those who were touched directly by the cessation of the independence of their congregation.

\section{Background}

Up to the arrival of the so-called "Second Wave" of German immigrants to the Western Cape, the geographical area of the Cape Flats was to a great extent uninhabited. ${ }^{6}$ Geographical studies of the area from the mid-1900s ${ }^{7}$ indicated that the Cape Flats had previously been a sea strait, with the Peninsula Mountain range an island.

Joubert describes the area as a "flat, even terrain of sand" that is marked by vlei areas. On these even flats there are smaller sand dunes in certain areas, and in many areas the water table during the rainy season is above the ground. ${ }^{8}$

4 W.J.L. Blumer (ed), Pflanzgarten im Dünensand (Wynberg, 1959), p. 25; L. Rabe, 'n Kultuurhistoriese studie van die Duitse nedersetting Philippi, p. 110.

L. Rabe, 'n Kultuurhistoriese Studie van die Duitse nedersetting Philippi, p. 112.

L. Rabe, 'n Kultuurhistoriese studie van die Duitse nedersetting Philippi, pp. 9-16.

H. Joubert, Die verstedeliking van die Kaapse Vlakte (D.Phil-proefskrif, Universiteit van Stellenbosch, 1956); M.S. Taljaard, A glimpse of South Africa (Stellenbosch, 1949). H. Joubert, Die verstedeliking van die Kaapse Vlakte, p. 27. 
In 1928 an archaeological discovery was made "on an old land surface in a sand quarry $[\ldots]$ at a depth of $6 \mathrm{ft}$, together with a thighbone and Middle Stone Age tools". 9

A descendant of the German immigrants who knew the ground formations intimately was the so-called "Sandkönig" (sand king) of the community, Gottfried (Freddy) Hubach (a descendant of the Second Wave-immigrants). This entrepreneur mined sand for building and glass manufacturing purposes. According to a newspaper report he discovered during his excavations implements of the Khoi (called "Strandlopers" in the report), sea fossils, grinding stones as well as skeletons of probably Khoi origin. ${ }^{10}$

It is not clear when after the arrival of Jan van Riebeeck Europeans started to settle the Cape Flats. Several sources maintain that it was uninhabitable due to various factors. ${ }^{11}$ One source gave this vivid description: ${ }^{12}$

Not a road, nor an alley, led through this area. You could not see a tree or shrub. Except for a pitiful type of heather, only brushwood grew. In January and February, in the time of the summer heat, the Flats were one sand and dust desert; in July and August, on the other hand, because of the winter rain, a huge vlei and marsh. Without interruption one could see right to Claremont and Wynberg. The soil was uncultivated and sterile. The trade winds of summer blew the loose sand all over. ${ }^{13}$

Schnell describes the area as "practically useless," 14 although this "weite, öde Sandund Heidefläche"15 (wide, barren sand and heath flats) were so beautiful in spring that it conjured up the following comparison: ${ }^{16}$

9 D.J. Potgieter (ed.), Standard Encyclopaedia of South Africa III (Cape Town, 1970), p. 31. 10 Die Burger, 1950-05-06.

11 L. Rabe, 'n Kultuurhistoriese studie van die Duitse nedersetting Philippi, pp. 13-14.

12 W.J.L. Blumer (ed), Pflanzgarten im Dünensand, p. 13.

13 Weder Weg noch Steg fuhr durch dieses Gebiet. Man sah keinen Baum noch Strauch. Ausser einer kümmerlichen Heideart wuchs nur noch ein kleines Gestrüpp. Im Januar und Februar, zur Zeit der Sommerhitze, war die ganze Vlakte eine Sand- und Staubwüste; im Juli und August dagegen, während der Winterregen, ein grosser See und Morast. Ungehindert konnte man aus der Vlakte bis nach Claremont und Wynberg hineinsehen. Der Boden war unbearbeitet und gänzlich unfruchtbar. Die im Sommer vorherrschenden Südostwinde trieben den losen Sand überall vor sich her.

$14 \quad$ E.L.G. Schnell, For men must work, p. 224.

15 H. Ludewig, Geschichte der Deutschen Evangelisch-Lutherischen St. Johannis-Gemeinde, p. 28.

16 H. Ludewig, Geschichte der Deutschen Evangelisch-Lutherischen St. Johannis-Gemeinde, p. 28. 
... in spring they were covered with a carpet of the most beautiful and loveliest flowers. It looked as festive as the world during its creation. ${ }^{17}$

To summarise, to a great extent the Cape Flats was uninhabited before the arrival of the first German immigrants as it was seen as an inhospitable semi-desert.

\section{First settlement}

In the same period as the official immigration projects of the British colonial government to establish German Settlers in the Eastern Cape,$^{18}$ several individual German families also migrated to the Western Cape. In the comprehensive Rabe study of the German immigrants to Philippi ${ }^{19}$ these immigrants were identified as the Godeffroy settlers, as they arrived on the Hamburg Godeffroy and Son shipping line to the Western Cape.

They were contracted by farmers in the Swartland area and had to work for a fixed period for their employees. After the expiration of their contracts, when they were "free men", they settled in the vicinity of Wynberg because of the Lutheran church there. Thus the church, and the successful settlement of these first settlers in this area, directly led to the decision of the Cape colonial government to populate the area with more German immigrants, as they had shown that the sandy area could indeed be cultivated.

These first immigrants were mostly Prussians, and some of the family names that became part of the bigger community of German immigrants were Trautmann, Rix, Thiele, Setzkorn, Schultz, Wesner, Karg, Gerstner, Reinke, Tank, Bröcker, Bock, Ellmann, Werth, Mohr and Buske. ${ }^{20}$ Of these, especially the Rix and Ellmann families are still prominent in the St Johannis congregation, and will be referred to later in this article.

17 ... im Frühjahr [war sie] übersäet mit einem Teppich der schönsten und zartesten Blumen. Feierlich ruhig wie die Welt am Schöpfungstage, so lag sie da. studie van die Duitse nedersetting Philippi op die Kaapse Vlakte (University of Stellenbosch, 1994). Vlakte (University of Stellenbosch, 1994).

L. Rabe, 'n Kultuurhistoriese studie van die Duitse nedersetting Philippi, pp. 611-613. 


\section{The St Johannis Congregation}

In the first half of the nineteenth century, members of the congregation of the Strand Street's "holländisch-lutherische Kirche" ${ }^{21}$ lived in the Wynberg area. ${ }^{22}$ Shortly after 1850 the Swedish brewer Letterstät brought about thirty Swedes - all Lutherans - to the Newlands area. The Lutherans in this area now felt they were strong enough in numbers to have their own congregation. In 1852 an affiliate parish of the Strand Street congregation was founded in Wynberg. ${ }^{23}$ However, this church never functioned properly, and due to internal strife in the Strand Street congregation, a German Lutheran church (St Martini in Long Street) was founded in 1861 with the eventual Lutheran congregation in Wynberg as a part of this new grouping. ${ }^{24}$ The first German service in Wynberg was held in September $1861 .^{25}$ This date is also regarded as the founding date of the Wynberg congregation.

Thanks to these "separierte" (separated) Lutherans, the Wynberg affiliate parish was started, but it was especially the "neu zukommenden deutsche Landsleute" (the newly arrived German compatriots) who gave the Wynberg congregation its right of existence. ${ }^{26}$ They were the Godeffroy immigrants who settled in the Wynberg area, mainly from 1865 to 1867 , up to the middle of the 1870s, who gave the Wynberg congregation this "rechten Bestand" (the right permanency). ${ }^{27}$

Amongst the vineyard workers in Constantia were Setzkorn, Rix and Trautmann. ${ }^{28}$ Some of the Godeffroy immigrants who worked on farms in the Malmesbury district for a specified period, after which they were free to move, were Ellmann, Bröcker, Schultz, Karg, Mohr, Bock and Reinke. ${ }^{29}$

21 H. Ludewig, Geschichte der Deutschen Evangelisch-Lutherischen St. Johannis-Gemeinde, p. 9.

W.H.C. Hellberg, Die Deutschen Evangelisch-Lutherischen Kirchengemeinden im Westen des Kaplands (D.Phil.-thesis, University of Stellenbosch, 1957), p. 150.

H. Ludewig, Geschichte der Deutschen Evangelisch-Lutherischen St. Johannis-Gemeinde, p. 11 .

W.H.C. Hellberg, Die Deutschen Evangelisch-Lutherischen Kirchengemeinden, p. 150.

H. Ludewig, Geschichte der Deutschen Evangelisch-Lutherischen St. Johannis-Gemeinde, p. 13.

H. Ludewig, Geschichte der Deutschen Evangelisch-Lutherischen St. Johannis-Gemeinde, p. 12 .

H. Ludewig, Geschichte der Deutschen Evangelisch-Lutherischen St. Johannis-Gemeinde, p. 22 .

H. Ludewig, Geschichte der Deutschen Evangelisch-Lutherischen St. Johannis-Gemeinde, p. 16 .

L. Rabe, 'n Kultuurhistoriese studie van die Duitse nedersetting Philippi, p. 20. 
These Godeffroy immigrants travelled from Hamburg on sailing ships. The voyage lasted two to three months. ${ }^{30}$ In a hand-written memory of Ernestine Rix, born Singer, she tells of the journey to Africa. The memoir was probably written in the 1930s (when she was in her eighties), and, according to the handwriting, probably written down by a child or grandchild. Ernestine, born on October 261853 , turned six during the journey. The sailing ship Victoria left Hamburg on October 1 1859. As the Rix family formed one of the "corner stone families" of the Wynberg church, and still feature prominently in the congregation, it merits the inclusion in this article of some of the memoirs of one of its very first members. The mistakes in the Rix manuscript are left unchanged: ${ }^{31}$

In the year 1859 we came to Africa, on the sail ship 'Victoria' with four other families. I have never forgotten the name, because we children sung Now we sail on the ship Victoria, hurrah, hurrah, to Africa. We were on the sea for four months before we arrived. The food was only cured meat, beans and peas, and the water always scarce, often the one would poach the other's. ${ }^{32}$

They were offloaded in baskets from the ship onto a rowing boat. Again Ernestine Rix $^{33}$ :

At the time, there were no docks[,] we were brought to the shore by row boat. But the fright when we children saw black people. Everyone cried[.] [T] he children clung to their mothers. We were brought to a place where the farmers were already waiting with their ox wagons to transport us. ${ }^{34}$

H. Ludewig, Geschichte der Deutschen Evangelisch-Lutherischen St. Johannis-Gemeinde, p. 20 . E.Rix, born Singer, Herinneringe-manuscript, ca.1930's, without pagination. Im Jahre 1859 kamen wir heraus nach Afrika mit vier Familien auf dem Segelschiff Victoria'. Der Name habe ich nie vergessen denn wir Kinder haben immer gesungen Jetzt fahren wir auf dem Schiff Victoria, Hurra, Hurra, nach Afrika. Drei Monate sind wir auf dem Wasser hin und her gefahren bis wir ans Land kamen. Die Speise war nur zaltz Fleisch, dicke Bohnen und dicke Erbzen und das Wasser war immer sehr knapp, oft hat eine den andern seins gestohlen.

33 E.Rix, born Singer, Herinneringe-manuscript, ca. 1930's, without pagination.

$34 \quad Z u$ der Zeit gab es keine Docks' wir wurden im Kahn am Land gebracht. Aber der Schrecken für uns Kinder als wir den schwarzen Leute sah. Das gab ein Gebrüll die Kinder klammert sich alle an ihrer Mütter. Wir kamen alle an einen Platz und die Bauern stand schon mit dem Ochsenwagen bereid uns ab zu hohlen. 
On the farms many worked like "slaves," ${ }^{35}$ as also Ernestine Rix remembered: "36 "Then the slavery began, the old farmers still had something of the slavery in them." ${ }^{37}$ The opposite was also true: some German families were treated as part of the family on the farms, and some of them in 1911 still had friends on farms where their parents worked and they had grown up, ${ }^{38}$ although they had worked extremely hard: ${ }^{39}$

The men and their sons had to work in the fields and the women and girls had to work as maids in the house of the employer. But they did succeed. The father of one our most prominent farmers, for example, did not have one single penny of his meagre earnings paid out until his debt for the voyage was settled. In his few free hours, he earned some pocket money through repair work to buildings and cutlery. With these earnings he bought himself a couple of hens and some sheep. ${ }^{40}$

Ernestine Rix also remembered: ${ }^{41}$

Our place was between Marmery [Mamre] and Darling and was called Karmelkfontein. It took us three days to get from Cape Town to this place. At the time everything was still a wilderness. There we stayed for three years and had to work off our passage [...] My father had to go to the fields at three in the mornings[.] [A]t the time they still harvested wheat with a sickle. ${ }^{42}$

H. Ludewig, Geschichte der Deutschen Evangelisch-Lutherischen St. Johannis-Gemeinde, p. 21.

E.Rix, born Singer, Herinneringe-manuscript, ca. 1930's, without pagination. Da fing die Sklaverei an, denn die alten Bauern hatten noch etwas von die Sklaverei in sich.

H. Ludewig, Geschichte der Deutschen Evangelisch-Lutherischen St. Johannis-Gemeinde, p. 21.

W.J.L. Blumer (ed), Pflanzgarten im Dünensand. (Wynberg, 1959).

Die Männer und ihre Buben mussten auf den Feldern arbeiten und die Frauen und Mädchen im Hause der Herrschaft Mägdedienste leisten. Aber sie schafften es doch. Der Vater eines unserer angesehensten Farmer hat z.B. nicht einen Penny seines karges Lohnes auszahlen lassen, bis seine Schuld für die Überfahrtskosten ganz getilgt war. In seinen wenigen Feierstunden verdiente er sich durch Flickarbeiten und Reparaturen an Gebäuden und Geschirr ein kleines Taschengeld. Damit kaufte er sich einige Hühner und Schafe. E. Rix, born Singer, Herinneringe-manuscript ca 1930's, without pagination.

42 Unser Platz war zwischen Marmery [Mamre] und Darling es hiess Karmelkfontein. Von Kapstadt bis an den Platz sind wir drei Tage gefahren. Dazumahl war es alles noch eine Wilderness. Da sind wir drei Jahre gewesen und müssten wir unser Passage abarbeiten [...] Mein Vater musste schon Morgens um drei mit aufs Land zu der Zeit snitten sie noch alle Ernte mit der Ziekel. 
After the expiration of these contracts, the immigrants as free people reverted to various entrepreneurial activities, from buying fish and hawking it on the platteland ${ }^{43}$ to hiring ground at "Clastenbosch" (Klaasenbosch, Constantia) to cultivate vegetables. ${ }^{44}$ The Flats still lay "fast ganz unbebaut und unbewohnt" (almost entirely uncultivated and uninhabited). ${ }^{45}$ Yet, the Germans who settled in the vicinity of Wynberg (Diepriver, Constantia, Tokai, etc) formed the foundation for the Wynberg congregation which the settlers of 1877/78 would join. The daughter of the first pastor of the St Martini congregation, Ludolf Parisius, who accompanied her father every three weeks to Wynberg for the service there, could still remember in 1911 what it was like. She also remembered: 46 "After the service there was a lot to discuss, some tears to dry. Some were physically sick, and the heart also ached with longing to their home." ${ }^{47}$ Ernestine Rix also remembered how they went to church: ${ }^{48}$ "In the beginning, we rode with the ox wagon to church. And many who lived even further away, took two hours to walk to church." 49

When Parisius fell ill and returned to Germany, St Martini and Wynberg were left with a vacancy for two years. ${ }^{50}$ Retired ministers from the Rhenish Missionary, such as Georg Krönlein, who wrote the first Damara grammarbook and dictionary, and E.H. Hahn, who did the same for the Herero language, officiated during this time. The latter was persuaded to accept the position, and officiated from 1874 to $1884 .{ }^{51}$

Members of the congregation lived mostly on the edges of what was known as the Wynberg and Claremont Flats. Ernestine Rix remembers what it looked like: ${ }^{52}$

43 H. Ludewig, Geschichte der Deutschen Evangelisch-Lutherischen St. Johannis-Gemeinde, p. 20.

H. Ludewig, Geschichte der Deutschen Evangelisch-Lutherischen St. Johannis-Gemeinde, p. 22.

H. Ludewig, Geschichte der Deutschen Evangelisch-Lutherischen St. Johannis-Gemeinde, p. 22 .

H. Ludewig, Geschichte der Deutschen Evangelisch-Lutherischen St. Johannis-Gemeinde, p. 23 . Nach dem Gottesdienst gab es manches zu besprechen, manche Träne zu trocknen. Mancher war krank an Leib und das Herz heimwehkrank. E.Rix, born Singer, Herinneringe-manuscript, ca 1930's, without pagination. Mit der Oksenkarre sind wir zur Kirchen gefahren im Anfang. Und viele die noch weiter waren, sind zwei Stunden gelaufen zu der Kirche.

50 W.H.C. Hellberg, Die Deutschen Evangelisch-Lutherischen Kirchengemeinden, p. 271.

51 H. Ludewig, Geschichte der Deutschen Evangelisch-Lutherischen St. Johannis-Gemeinde, p. 25 .

52 E.Rix, born Singer, Herinneringe-manuscript, ca 1930's, without pagination. 
"The Flats and Dunes were one desert. Here and there were houses, miles apart. From Simon's Town to Wynberg there were almost no houses and no street." ${ }_{33}$

Two Godeffroy immigrants were the first to buy property on the Flats. They were Carl Wesner and Christian Schultz. ${ }^{54}$ Wesner was officially a Godeffroy immigrant, as he arrived on this line, but came "auf eigene Unkoste und auf eigenes Risiko" (on own costs and own risk) to the Cape. ${ }^{55}$ Schultz worked for more than eleven years on his contractor's farm in Malmesbury in order to save enough money to buy his own property..$^{56}$ According to one source, this property was bought in $1876 .{ }^{57}$

The original Wynberg congregation grew slowly, but steadily. According to one source, twenty German families resided in the area before the arrival of the 1877/ 78 immigrants. ${ }^{58}$ Many of the first German immigrants on the Flats remained loyal members of the Wynberg congregation. The big families also provided growth: Ernestine Singer and Gottfried Rix had thirteen children, eight of them sons. ${ }^{59}$

Until the sixties and seventies of the nineteenth century, treating the Wynberg congregation as an affiliate parish of the Cape congregation, seemed in order - until "eine erneute grosse deutsche Einwanderung" (a new big German immigration), to be identified later as the Second Wave, demanded a change in this status quo. ${ }^{60}$

\section{The 1877/78 immigrants}

German immigrants to the Eastern Cape proved that families could exist on smaller pieces of land. ${ }^{61}$ Cape Colony minister John X Merriman, on his journeys to the Eastern Cape, was "surprised" to find "prospering"62 German towns: "If German settlers could change 'a stone desert into a paradise' [...], why not also a sand desert?"63 The result was the arrival of the immigrants of the Second Wave, in 1877 and 1878 , soon to be followed by those of the Third Wave in 1883 .

53 Die Vlackte und Düne war nur eine Wüsste. Hier und da Meilen weit stand die Häuser auseinander. Von Simonstadt bis an Wynberg war beina[sic] keine Häuser und keine Strasse. E. Rix, born Singer, Herinneringe-manuscript, ca 1930's, without pagination. W.J.L. Blumer (ed), Pflanzgarten im Dünensand, p. 13.

W.J.L. Blumer (ed), Pflanzgarten im Dünensand, p. 13.

I. Bode, born Schultz, Manuscript, 1983, without pagination.

W.J.L. Blumer (ed), Pflanzgarten im Dünensand, p. 13.

W. Schmidt-Pretoria, Deutsche Wanderung nach Südafrika im 19. Jahrhundert (Berlin, 1955), p. 118.

59 Interview: Ilse Ellmann, born Freiboth. Philippi, 1992.

60 H. Ludewig, Geschichte der Deutschen Evangelisch-Lutherischen St. Johannis-Gemeinde, p. 26.

$61 \quad$ E.L.G. Schnell, For men must work, p. 201.

62 W.J.L. Blumer (ed), Pflanzgarten im Dünensand, p. 16.

63 W.J.L. Blumer (ed), Pflanzgarten im Dünensand, p. 16. 
Because of the reputation of the Godeffroy immigrants, the colonial government decided to focus on German immigrants ${ }^{64}$ :

When the immigration issue was raised again in the year 1875/76 the .. Kloete [sic], one of the biggest wine famers from Constantia, pleaded to bring German immigrants to South Africa. The Swartland Germans are the best recommendations for his plea, as they are characterised through industry, endurance, truthfulness and thrift. Those were the major characteristics that a government can expect from immigrants. ${ }^{65}$

According to the 1875 report of the Surveyor General there was a "considerable extent of un-alienated Government land in various parts of the Colony, specially adapted for agricultural purposes and valuable as a means of attracting immigration." ${ }^{66}$ According to the "List of Crown Land Lots surveyed for immigrants" large areas ${ }^{67}$ were then surveyed in the area known as "Zwart Dam" (Claremont and Wynberg Flats). Other areas in the Cape were also surveyed. Cloete, together with Merriman, particularly wanted to populate the Flats: ${ }^{68}$

... both focused especially on the flats, the Vlakte, that lay between the Table Mountain and the mountains of Stellenbosch and Strand. Minister Merriman wanted to make the Vlakte the source of production for Cape Town's needed vegetables[.] ${ }^{69}$

Merriman was convinced that the moving sands due to wind could be controlled by trees and shrubs in order to cultivate the soil. For this, he announced a competition in

64 W.J.L. Blumer (ed), Pflanzgarten im Dünensand, p. 13.

65 W.J.L. Blumer (ed), Pflanzgarten im Dünensand, p. 13: Als nun in den Jahren 1875/76 im Parlament die Einwanderungsfrage wieder aufgenommen wurde, trat der Abgeordnete Kloete [sic], einer der grössten Weinfarmer von Constantia, energisch dafür ein, deutsche Einwanderer nach Südafrika zu bringen. Die Swartländer Deutschen seien die beste Empfehlung für seinen Antrag, denn sie zeichneten sich durch Fleiss, Ausdauer, Ehrlichkeit und Sparsamkeit aus. Das seien die Kardinalforderungen, die von der Regierung an Einwanderer gestellt werden müssen. E.L.G. Schnell, For men must work, p. 215. L. Rabe, 'n Kultuurhistoriese studie van die Duitse nedersetting Philippi, p. 30. W.J.L. Blumer (ed), Pflanzgarten im Dünensand, p. 13. zwischen dem Tafelgebirge und den Bergen von Stellenbosch und Strand ausbreitet. Minister Merriman wollte die Vlakte zur Produktionsquelle des von Kapstadt benötigten Gemüses machen[.] 
the Government Gazette in May 1877 for the best plantation of the first 50 acres, or if this were not possible, the best 25 acres, or, if this were not possible, the best 12 acres. $^{70}$

On 17 August 1876 Merriman concluded an agreement with the Cape Town agent Wilhelm Berg of the Godeffroy and Son Line as contractors to recruit immigrants for the Cape. ${ }^{71}$

The Hamburg "Auswanderer-Behörde" (Immigration department) distributed leaflets containing information on the immigration project and its prospects. One "subagent", Theodor Risler, described the settlement area in "glühenden Wörten" ("glowing words"). ${ }^{72}$ Because many of the prospective immigrants were peasants, they were eager and willing to commit themselves to a new future. However, stipulations in the newly adopted "Agricultural Immigrants Lands Act, no 10, 1877" were not conveyed to them. Property could be leased for ten years, at a shilling per acre per year, and at least ten acres had to be cultivated after two years, together with a home valued at least at $£ 20 .{ }^{73}$ For immigrants arriving with no means other than their work ethic - as it was described: their "Lutheran Bible and a pair of hands" 74 - this would prove to be exceptionally difficult.

Complete hand-written lists can be found in the Cape Archives of eight of the immigration ships. ${ }^{75}$ These contained the names of the immigrants, their ages, sex, profession, wives' names and ages, and children's names and ages. Not only immigrants to the Western Cape, but also to the Eastern Cape arrived. According to Hellberg eight ships arrived, but according to both Schnell and Schmidt-Pretoria ten arrived. ${ }^{76}$ According to another list with less information than the first, nine vessels brought immigrants to the Western Cape. ${ }^{77}$

Unlike the Godeffroy First Wave immigrants, these newcomers were on arrival "vollständig freie Herren" (entirely independent men). They could settle wherever they wanted, and there were also employers on arrival waiting to "secure their services" ${ }^{78}$ On arrival it was explained to them that they need not take the land that government gave them when it did not suit them. ${ }^{79}$

70 W.H.C. Hellberg, Von den deutschen Siedlern im Kapland, Afrikanischen Heimatkalender, 1954.

${ }_{71}$ L. Rabe, 'n Kultuurhistoriese studie van die Duitse nedersetting Philippi, p. 31.

72 W.H.C. Hellberg, Von den deutschen Siedlern im Kapland, Afrikanischen Heimatkalender, 1954.

73 L. Rabe, 'n Kultuurhistoriese studie van die Duitse nedersetting Philippi, p. 33.

74 L. Rabe, 'n Kultuurhistoriese studie van die Duitse nedersetting Philippi, 1994.

75 L. Rabe, 'n Kultuurhistoriese studie van die Duitse nedersetting Philippi, p. 33.

76 L. Rabe, 'n Kultuurhistoriese studie van die Duitse nedersetting Philippi, p. 33.

77 L. Rabe, 'n Kultuurhistoriese studie van die Duitse nedersetting Philippi, p. 34.

79 H. Ludewig, Geschichte der Deutschen Evangelisch-Lutherischen St. Johannis-Gemeinde, p. 27 . 
These 1877/78 settlers can be divided into three groups: those whose services were contracted by employers, those who settled on the designated areas in the Wynberg and Claremont Flats, and those who settled in the Boland. ${ }^{80}$

Those who headed for the Flats, apparently barely arrived in Cape Town before they were warned of what was waiting for them ${ }^{81}$ :

... when the ship sailed into Table Bay, they saw no reason to doubt Risler [the immigration agent Theodor Risler]. But they were barely in Cape Town, and drew the lot for their pieces of land, or they were told [...] that they have to prepare themselves for bitter disillusionment. They were accordingly somewhat prepared. But that the land would be so desert-like, they could never have thought. ${ }^{82}$

Altogether 20 families were settled on the Wynberg Flats and 21 on the Claremont Flats.

In addition there is every justification for the assumption that many others settled there subsequently, after first earning a little money to enable them to start with at least some capital in hand. ${ }^{83}$

The only service the Cape government had prepared for the arrival of the settlers was to survey the properties. ${ }^{84}$ "The surveyors marked the areas with border posts. The moving sand, however, covered these posts. One had to dig before one could find them." ${ }^{85}$ No access roads had been made to the area, nor were roads provided for in the area ${ }^{86}$ The Dutch ridiculed the Germans: ${ }^{87}$ "In winter you will drown in water, and in summer you will die of thirst." $" 88$

The immigrants lived in tents until they could erect better structures (made from bulrush and clay, the only material available). Men sought employment in town

$80 \quad$ E.L.G. Schnell, For men must work, p. 223.

81 W.H.C. Hellberg, Von den deutschen Siedlern im Kapland, p. 93.

... als das Schiff in die Tafelbai hineinsegelte, sahen sie keine Ursache, Rislers [the immigration agent Theodor Risler] Worten nicht zu glauben. Aber kaum waren sie in Kapstadt, und hatten das Los für ihre Siedlungsfarmen gezogen, so wurde ihnen [...] gesagt, dass sie sich auf bittere Enttäuschung gefasst machen müssten. Sie waren daher schon ein wenig vorbereitet. Dass ihr Land aber so wüstenartig seien würde, hatten sie keineswegs gedacht. E.L.G. Schnell, For men must work, p. 224.

W.H.C. Hellberg, Von den deutschen Siedlern im Kapland, p. 93.

Die Landmesser hatten Grenzbaken in den Boden getrieben. Der bewegliche Sand hatte aber diese Grenzbaken verdeckt. Man musste graben, ehe man sie finden konnte.

L. Rabe, 'n Kultuurhistoriese studie van die Duitse nedersetting Philippi, p. 41.

H. Ludewig, Geschichte der Deutschen Evangelisch-Lutherischen St. Johannis-Gemeinde, p. 28.

In de winter zal jullie verzuipen in water, en in de zomer verrekken van dorst. 


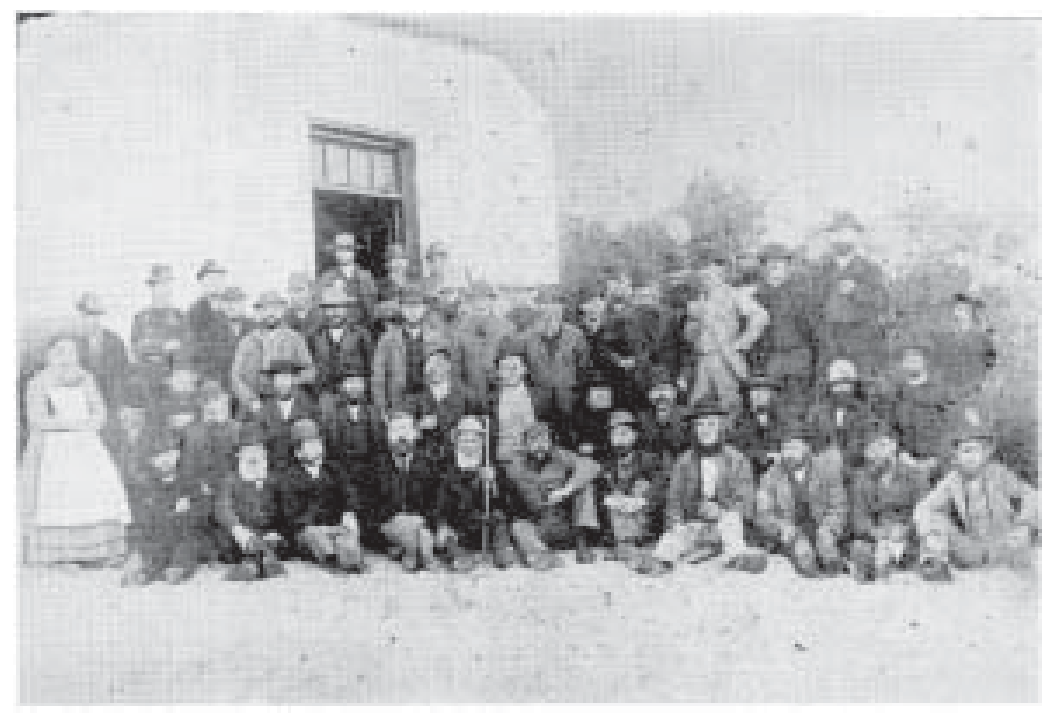

Figure 1. A photograph taken in 1888 of mainly settlers of the 1877/78 and 1883 groups. In the background is the first school which was built in 1886. The picture originally belonged to the author's grandfather, Wilhelm Rabe, and was used in the publication by (W.J.L. Blumer (ed), Pflanzgarten im Dünensand, Wynberg, 1959, p. 32.)

or the southern suburbs, while the women and children tried to cultivate the sand. On weekends the men returned with their earnings of $2 / 6$ to 3 shillings, and did their bit to bring the efforts "noch möglich vorwärts" (improve the efforts). ${ }^{89}$ Schnell wrote: "At first the work was difficult and disappointing, their initial attempts failed lamentably. All their experience in Germany availed them nothing, here they had to begin learning afresh." ${ }^{0}$

Not only their socio-economical condition, the elements, climate and general circumstances were against the German peasants who sought a better future in a new country, but to add to their misery, the newly arrived immigrants were treated with the greatest contempt by the Cape gentry who regarded the Flats as their hunting grounds.

H. Ludewig, Geschichte der Deutschen Evangelisch-Lutherischen St. Johannis-Gemeinde, p. 29.

$90 \quad$ E.L.G. Schnell, For men must work, p. 225.
} 
Apparently the hunting club drove through the newly established small fields "ohne sich ein Gewissen daraus zu machen" (without taking it seriously), and it occurred very often that the "stampfenden Hufe der galloppierende Pferde" (stampeding hooves of the galloping horses) destroyed within moments the hard work of weeks. ${ }^{91}$

Another source recorded how one immigrant was humiliated by the hunters. After the hounds tackled his newly acquired hens, he apparently grabbed the nearest horse by its bridle, whereupon the whole group attacked him. When he was prostrate on the ground, they continued attacking him, then drove off without even looking back at him. The complaint yielded nothing - the magistrate had also been a member of the hunting club, and indeed, also took part in the attack. ${ }^{92}$ The immigrants realised they could not expect any justice, and would just start all over again as soon as the hunting club had left. ${ }^{93}$

The Dutch farmers in the vicinity also did not look upon the newcomers favourably, as they regarded the entire Flats as grazing for their cattle, or for cutting reeds for thatch:

[They] objected to the ground, which they had used for years, being given to the Germans, and continued grazing their cattle there. Sometimes they drove their stock into the gardens which the Germans had as yet not been able to enclose. The men were often absent at work in town and when the women remonstrated, they were laughed at. If the Germans did succeed in taking the cattle to drive them to the pound, they were forcibly taken from them. ${ }^{94}$

To add to the misery, the Germans who wanted to sell their small harvest in town had to have a licence, the existence of which they did not know - and which they could not afford. ${ }^{95}$

In the first years the settlers did many things for no gain; it was a hard lesson they had to learn [...] One has to admire them, that they, after all these mishaps, always would start anew. ${ }^{96}$

\footnotetext{
$91 \quad$ W.H.C. Hellberg, Von den deutschen Siedlern im Kapland, p. 94.

92 W.J.L. Blumer (ed), Pflanzgarten im Dünensand, p. 18.

93 W.H.C. Hellberg, Von den deutschen Siedlern im Kapland, p. 94.

$94 \quad$ E.L.G. Schnell, For men must work, p. 225.

95 H. Ludewig, Geschichte der Deutschen Evangelisch-Lutherischen St. Johannis-Gemeinde, p. 29.

96 H. Ludewig, Geschichte der Deutschen Evangelisch-Lutherischen St. Johannis-Gemeinde, p. 29: In den ersten Jahren haben die Ansiedler viel Arbeit umsonst getan; ein teures Lehrgeld haben sie zahlen müssen [...] Man muss sie bewundern, dass sie nach vielen Misserfolgen immer noch einmal von neuem zu Spaten und Hacke gegriffen haben.
} 
Although stories abound of how difficult the first year was, all the settlers could pay their first instalment for their properties at the end of the year. The majority managed to erect a "provisorische Hütte" (provisional hut) ${ }^{97}$

The arrival of these immigrants meant that the affiliate congregation in Wynberg grew substantially over a very short period. Their spiritual needs called for a pastor of their own. In 1882 the question was asked whether the affiliate congregation should become independent. ${ }^{98}$ In November that year it was decided that each family should give $£ 2 / 50$, and individuals over $21, £ 1$, to finance a pastor of their own, together with the leasing of benches in church. However, enough money could not be raised. With the news of the next wave of immigrants due to arrive in 1883, some of the $1877 / 78$ immigrants petitioned for a church of their own closer to their properties. ${ }^{99}$

In 1878 Merriman, in his closing speech for that year's session, reported in parliament that the "useless" crown property had been put to good use and that the peasants had been successful thanks to their work ethic.

Thus while rendering a great service to their adopted country by utilizing what had until then been practically waste land, and by demonstrating the possibility of close settlement, even under unfavourable circumstances, these German immigrants of 1877 and '78 had found happiness for themselves. Thus in a few years the Germans have changed everything: they had made a fruitful garden out of a wilderness - and at the same time were well on the way to prosperity themselves. ${ }^{100}$

According to one Public Works Department document the total of German immigration for the decade 1872 to 1882 was $2149 .{ }^{101}$

\section{The 1883 immigrants}

Apparently Merriman planned to bring 15000 more German immigrants to the Cape, and the next official immigration project was planned for 1883. The Cape of Good Hope General Directory of 1883 reported:

\footnotetext{
$97 \quad$ W.H.C. Hellberg, Die Deutschen Siedlungeng in Südafrik, 1954.

98 H. Ludewig, Geschichte der Deutschen Evangelisch-Lutherischen St. Johannis-Gemeinde, p. 32 .

99 H. Ludewig, Geschichte der Deutschen Evangelisch-Lutherischen St. Johannis-Gemeinde, p. 33.

100 E.L.G. Schnell, For men must work, pp. 224-225.

101 L. Rabe, 'n Kultuurhistoriese studie van die Duitse nedersetting Philippi, p. 50.
} 
The settlements on the Cape Flats, almost exclusively German, are perhaps the most encouraging of any undertaken by the Government. ...So greatly have they contributed towards arresting the progress of the sanddrifts on the flat stretch of country between False and Table Bays, that the Government is about to introduce a large party of their countrymen for the same object. ${ }^{102}$

The next group of immigrants would come via an agreement with the Union Steamship Company. ${ }^{103}$ The project brought 77 families and a number of bachelors to the Cape. Despite the glowing report by Merriman in terms of how they viewed the initial success of the $1877 / 78$ immigrants, the fact that they could not raise enough money for their own pastor in 1882 , also meant that they probably could not assist the newcomers in any material way, as one historian recorded: "hier in der Vlakte standen sie vor einem völligen Nichts" (here in the Flats they stood in front of a total nothingness). ${ }^{104}$ The realities were described as follows: ${ }^{105}$

Without money, without livestock, without the simplest tools, as only capital a pair of hard fists and a brave heart... There was probably no one among the immigrants who heard so many promises about their unknown future as did they from their recruiters. They [the agents] all knew that it concerned an uninhabited, maybe infertile land, which they were supposed to cultivate. What the farmers found at the Cape, however, even surpassed all expectations. ${ }^{106}$

Their perseverance, graphically described in the following, ${ }^{107}$ became legendary amongst their descendants:

Through hardy, sacrificial labour, they managed to settle, although step by step. The little piece of attributed land was bought, a small hut from lattices

\footnotetext{
102 L. Rabe, 'n Kultuurhistoriese studie van die Duitse nedersetting Philippi, p. 53.

103 L. Rabe, 'n Kultuurhistoriese studie van die Duitse nedersetting Philippi, p. 53.

104 W.J.L. Blumer (ed), Pflanzgarten im Dünensand, p. 13.

105 H. Bruckschen, Aus der Heide in die Vlakte, in W. Blumer (red), Pflanzgarten im Dünensand, p. 38 .

106 H. Bruckschen, Aus der Heide in die Vlakte, p. 38: Ohne Geld, ohne Vieh, ohne die einfachsten landwirtschäftlichen Geräte, als einziges Kapital ein Paar derbe Fäuste und ein mutiges Herz... Es war wohl niemand unter den Auswanderern, der sich von seiner unbekanntes Zukunft so viel versprach, wie es ihre Anwerber taten. Sie [the agents] wussten alle, dass es hier ein unbewohntes, vielleicht unfruchtbares Land zu bearbeiten, aufzubauen galt. Was die Bauern aber dort am Kap erwartet hat, muss alle Befürchtungen weit übertroffen haben.

107 H. Bruckschen, Aus der Heide in die Vlakte, p. 38.
} 
was built, and then they went about to save something for a couple of chickens or cattle by picking berries... When the barren soil then gave the first vegetables, they carried this through the roadless sand to Cape Town. The indescribable pains and hardships the first settlers suffered, who only negotiated for an own school and church for the preservation of their cultural and religious heritage [which was not fulfilled, as the immigrants built their own school, and later the two churches at Philippi and in the Dunes], managed to develop the Flats into a treasure trove. ${ }^{108}$

And so, the arrival of the last group of immigrants consolidated the community of German agricultural immigrants on the Cape Flats. According to a news report, a strong sense of community was forged, which was still evident in 1951 when the following was written:

Naturally enough, one finds a strong community feeling among these Philippi farmers. Their common background of endeavour would hold them together, even without their common original nationality. ${ }^{109}$

\section{Church in Wynberg, school in Philippi}

This community of immigrants now went to the church in Wynberg, although the newcomers felt they wanted to build a church closer to the settlement on the Flats proper.

The older immigrants naturally felt they wanted to conserve the strength of their church, and in the end it was decided that the school would be built in Philippi, and that all would remain members of the Wynberg church, still not independent of St Martini. ${ }^{110}$ The school was established directly under the leadership of the St Martini Church, and it was called the "Schulgemeinde". ${ }^{111}$

Durch zähe, aufopfernde Arbeit gelang es nur mühsam, Schritt für Schritt Fuss zu fassen. ... Das Stückchen zugeteilte Land wurde käuflich erworben, eine Hütte aus Flechtwerk zur Unterkunft gebaut, und dann ging man daran, durch Sammeln von wildwachsenden Beeren das Geld für enige Hühner oder für Vieh zusammenzusparen ... Als der öde Boden dann das erste Gemüse hergab, da musste man dieses ... durch den weglosen Sand nach Kapstadt tragen. Die unsäglichen Mühen und Entbehrungen dieser ersten Siedler, die sich als einziges eine Schule und Kirche für die Erhaltung ihres kulturellen und kirchlichen Erbes ausbedungen hatten [which was not fulfilled, as the immigrants built their own school, and later the two churches at Philippi and in the Dunes], haben die Vlakte zu einem Schatzkästlein werden lassen.

109 L. Rabe, 'n Kultuurhistoriese studie van die Duitse nedersetting Philippi, p. 588.

110 L. Rabe, 'n Kultuurhistoriese studie van die Duitse nedersetting Philippi, pp. 79-97.

111 L. Rabe, 'n Kultuurhistoriese studie van die Duitse nedersetting Philippi, p. 87. 


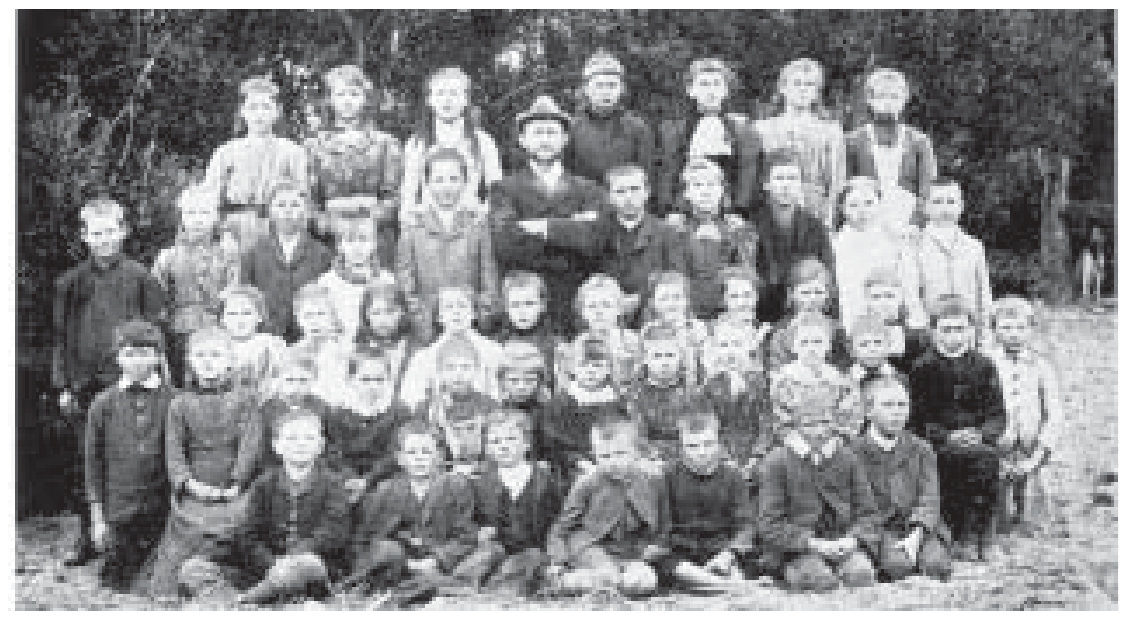

Figure 2. A group of children who attended the Philippi school, 1894. The photograph originally belonged to Emma Buhr (born Prigge). ${ }^{112}$

(W.J.L. Blumer (ed), Pflanzgarten im Dünensand, Wynberg, 1959, p. 33.)

In Wynberg there was still disagreement regarding the finances for the congregation's independence. ${ }^{113}$ The "Schulgemeinde" in Philippi no doubt contributed to this uneasiness. The colonial government bequeathed "trust ground" to the community in Philippi to build a proper school building (built by the immigrants themselves) and a cemetery. Because this had to be above the water table, a dune in the middle of the agricultural settlement, named "Zionshügel" was chosen. ${ }^{114}$ The church, eventually to be built, therefore became known as the "Zionskirche".

Pastor Wagener, in charge of both St Martini and Wynberg, did his utmost to help the "large and vast" Wynberg congregation to be more independent. In 1886 work on an own parsonage was started, ${ }^{115}$ and on New Year's day in 1887 the

112 The success with which the settlers planted the now illegal Port Jackson willow can be seen in the background - a thick cluster of trees. The Port Jackson willow was regarded as a "saving grace" by the settlers because it not only protected their fields from the Southeaster, but was used for many other purposes, such as animal feed, for firewood and in leather tannery - a subject which can be the focus of another article.

113 H. Ludewig, Geschichte der Deutschen Evangelisch-Lutherischen St. Johannis-Gemeinde, p. 36 .

114 L. Rabe, 'n Kultuurhistoriese studie van die Duitse nedersetting Philippi, p. 88.

115 H. Ludewig, Geschichte der Deutschen Evangelisch-Lutherischen St. Johannis-Gemeinde, p. 36 . 
congregation celebrated its independence, and was named the "Deutsche Evangelishlutherische St Johannis Gemeinde."116 Pastor Krönlein, who had previously worked in a part-time capacity in the congregation, was persuaded to become its first official pastor. ${ }^{117}$ However, the fact that those more supportive of the "Schulgemeinde" concentrated their financial contribution on its viability instead of the Wynberg church, caused discord.

The community could be divided, broadly speaking, into two groups: the Godeffroy settlers, more loyal to the Wynberg church, and those of the Second and Third Waves, who were more loyal to the Philippi "Schulgemeinde". Still, the decade ended with "Eintracht und Frieden" (concord and peace), in Pastor Krönlein's words, in the congregation. ${ }^{18}$

The next decade started with one congregation and one school serving the community, but ended with three churches and three schools: a church and school each in Wynberg, Philippi and the Dunes. After the sudden death of Pastor Krönlein in 1892 the newly appointed minister, Pastor Johann Heinrich Bracklo, could not unite the members, especially as he endeavoured to establish a school at the Wynberg church. ${ }^{119}$

In 189623 families of the Philippi Schulgemeinde distanced themselves from the Wynberg church and established the affiliate parish of St Martini in Philippi. ${ }^{120} \mathrm{In}$ 1897 the cornerstone of the Philippi church was laid, as well as that of the church in the Dunes, which would be named the Neu-Eisleben congregation, after the birth town of Martin Luther. ${ }^{121}$

\section{The last decade of the $1800 \mathrm{~s}$}

Although a great deal was said about the so-called "Schulstreit" by legendary hardheaded Germans from both Wynberg and Philippi at the beginning of the 1890s, this did not lead to a split in the community.

The families upheld friendship and family bonds: from the older, more established immigrants of the Godeffroy, and some families of the 1877/78 group who preferred to remain in the Wynberg congregation, to the families of the $1877 / 78$ and 1883 groups,

\footnotetext{
116 W.J.L. Blumer (ed), Pflanzgarten im Dünensand, p. 25.

117 H. Ludewig, Geschichte der Deutschen Evangelisch-Lutherischen St. Johannis-Gemeinde, p. 37.

118 W.H.C. Hellberg, Die Deutschen Evangelisch-Lutherischen Kirchengemeinden, p. 161.

119 H. Ludewig, Geschichte der Deutschen Evangelisch-Lutherischen St. Johannis-Gemeinde, p. 52 .

120 L. Rabe, 'n Kultuurhistoriese studie van die Duitse nedersetting Philippi, pp. 109-111.

121 L. Rabe, 'n Kultuurhistoriese studie van die Duitse nedersetting Philippi, pp. 11-113.
} 
who preferred to join the newly established church, as well as those who lived further away in the Dunes, for whom it was a practical issue to build their own church. Except for some bitterness in some corners, in retrospect, it was said that the "Bruch" (break) was a natural development because of the size of the congregation and the geographical realities. ${ }^{122}$

This decade could be concluded with a farming community that was solidly established - to such an extent that they could support one another through the rinderpest, and that they could exhibit prize winning vegetables at the Rosebank Show. Churches and schools were well supported. ${ }^{123}$ In the 1930s the life of both these accidental and incidental immigrants was described as follows: ${ }^{124}$

No wealth, but a humble existence, based on hard labour, and sustained by hard labour, that is what one finds here. Every week the loaded vegetable trucks drive through the deep sandy roads to Cape Town to take their green pride to the market. No one, standing in front of the selection trying to choose, would think that it is only thanks to the industry of German farmers that this blessing of God could be produced in the desert. ${ }^{125}$

\section{Fast forward: one century later}

Given this history, what led to the slow demise of the Wynberg church to the extent that it would become a parish affiliate of the Philippi church in 2007? The same dedication certainly persists amongst the descendants of the first Godeffroy immigrants.

Alfred Rix (Ernestine is his great-grandmother) is such a dedicated and passionate member of the Wynberg congregation. So is Ruth Ellmann, born Hörstmann, a descendant of the 1877-immigrants, who "married into" the Wynberg church as a member of the Philippi congregation in the early 1950s. Alfred Rix, born in 1947, was

\footnotetext{
122 H. Ludewig, Geschichte der Deutschen Evangelisch-Lutherischen St. Johannis-Gemeinde, p. 45 .

123 L. Rabe, 'n Kultuurhistoriese studie van die Duitse nedersetting Philippi, p. 131.

124 Deutsches Lesebuch für Gymnasien (Hamburg, 1939), p. 72.

125 Deutsches Lesebuch für Gymnasien, p. 72 Kein Reichtum, aber ein bescheidenes Auskommen, auf Arbeit gegründet und nur mit Arbeit erhalten, dass ist es, was einen hier entgegentritt. Allwöchentlich rollen die hochbetürmten Gemüsewagen durch die tiefen Sandwege der Vlakte auf die grosse Strasse nach Kapstadt, um dort ihre grüne Pracht auf den Markt zu bringen. Keiner, der wählend davor steh, denkt wohl daran, dass allein deutscher Bauernfleiss diesen Segen Gottes aus der Wüste geholt hat.
} 


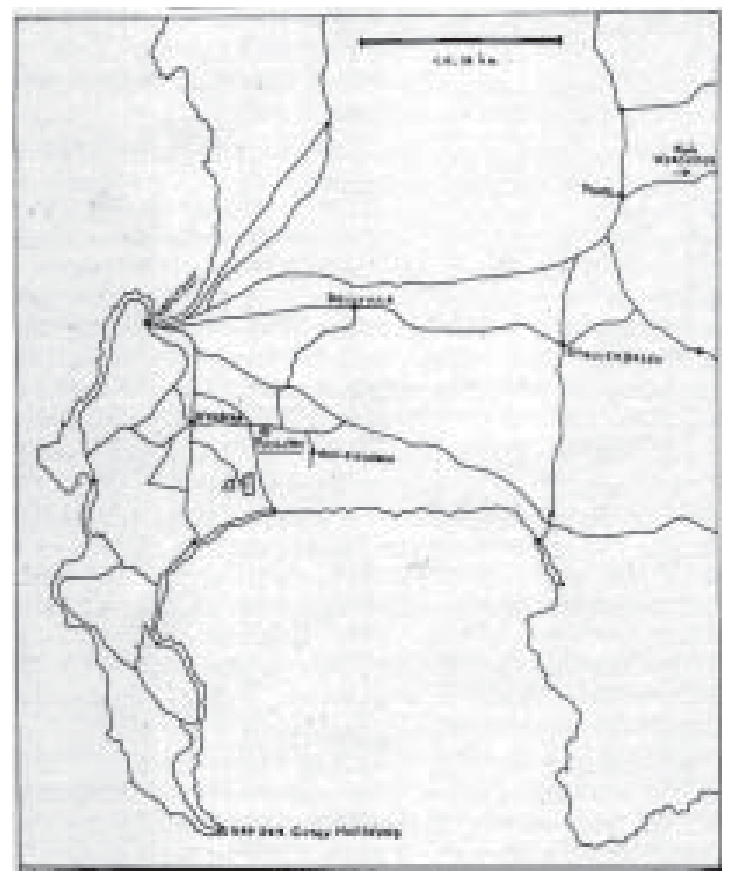

Figure 3. A map drawn by Pastor Wilhelm Blumer in 1959 indicating where the Wynberg, Philippi and Neu-Eisleben churches are situated in the Cape Peninsula. ${ }^{126}$

(W.J.L. Blumer (ed), Pflanzgarten im Dünensand, Wynberg, 1959, p. 8.)

a member of the "Vorstand" (church council) since shortly after his marriage in 1971, and since then he first served as deputy chairperson for 12 years and as chairperson for the past 12 years. Ruth Ellmann's husband, Heinrich Ellmann, now 80, has been a Wynberg stalwart for all of his active years.

According to Alfred Rix the St Johannis congregation has 186 members ${ }^{127}$ (the Philippi congregation has 406 members). When the current Wynberg pastor's contract expires in July 2007, the Philippi pastor, according to the parish agreement, will hold

The then agricultural area where the descendants of the settlers farmed, was around Philippi and Neu-Eisleben. The two irregular circles on the map indicate the location of Zeekoe- and Princessvlei. 
services in the Wynberg church, according to a certain schedule as stipulated by the agreement. To Alfred Rix, the agreement is part of a lifebouy for the Wynberg congregation, and he does not regard it in a negative light. The congregation, of which a very small percentage are active members, cannot raise the money needed to maintain its own pastor, and was indeed subsidised by the Cape Church (the Lutheran Synod in the Cape). For him the development has become necessary, purely as a "financial decision".

"Geld regiert die Welt" is also the opinion of the Philippi pastor, Arthur Becker (a descendant of the German immigrants to the Eastern Cape), who will now serve both congregations through the parish agreement. ${ }^{128}$ According to him, also, Wynberg's decision to move into a parish agreement had its origin in the diminishing number of members and the fact that the congregation struggled to meet its obligations towards the Cape Church. Pastors' salaries are paid out of these contributions, and the bigger congregations subsidised the smaller ones. However, it is not feasible to do so any longer.

According to Becker, the Lutheran church in the Eastern Cape has parish arrangements as a rule and not an exception. The congregations of Berlin, Potsdam and Macleantown, for instance, have an arrangement dating prior to the First World War. In the area of East London, heart of German immigration country in the Eastern Cape (with a monument in honour of the immigrants in the city), there is not one independent congregation left. Earlier, there were five pastors for 11 congregations, now there are only four. ${ }^{129}$

The congregation for which Alfred Rix has worked so hard all his life, will keep its own identity, although it will not have its own pastor any more. Of the old "pioneer" families, who have always worked hard for the upkeep, in a literal and figurative sense, of their church and congregation, there are just more than 30 members left. ${ }^{130}$

On the other hand, it is a "very sad" development for other members of the congregation, such as Ruth Ellmann. ${ }^{131}$ According to her, the "big reason" leading to this, is money, which the small and ageing congregation cannot provide. Whereas the normal structure for a congregation is a pyramid with a mass of children/youth at the bottom, and fewer seniors at the top, the opposite is true for Wynberg. ${ }^{132}$ Instead,

\footnotetext{
128 Email-interview: Arthur Becker, Pastor of the Philippi congregation, 2007-01-11.

129 Email-interview: Arthur Becker, Pastor of the Philippi congregation, 2007-01-11.

130 Interview: Alfred Rix, chair St Johannis church council, Philippi, 2007-01-09.

131 Interview: Ruth Ellmann, born Hörstmann, Philippi, 2007-01-08.

132 Interview: Alfred Rix, chair St Johannis church council, Philippi, 2007-01-09.
} 


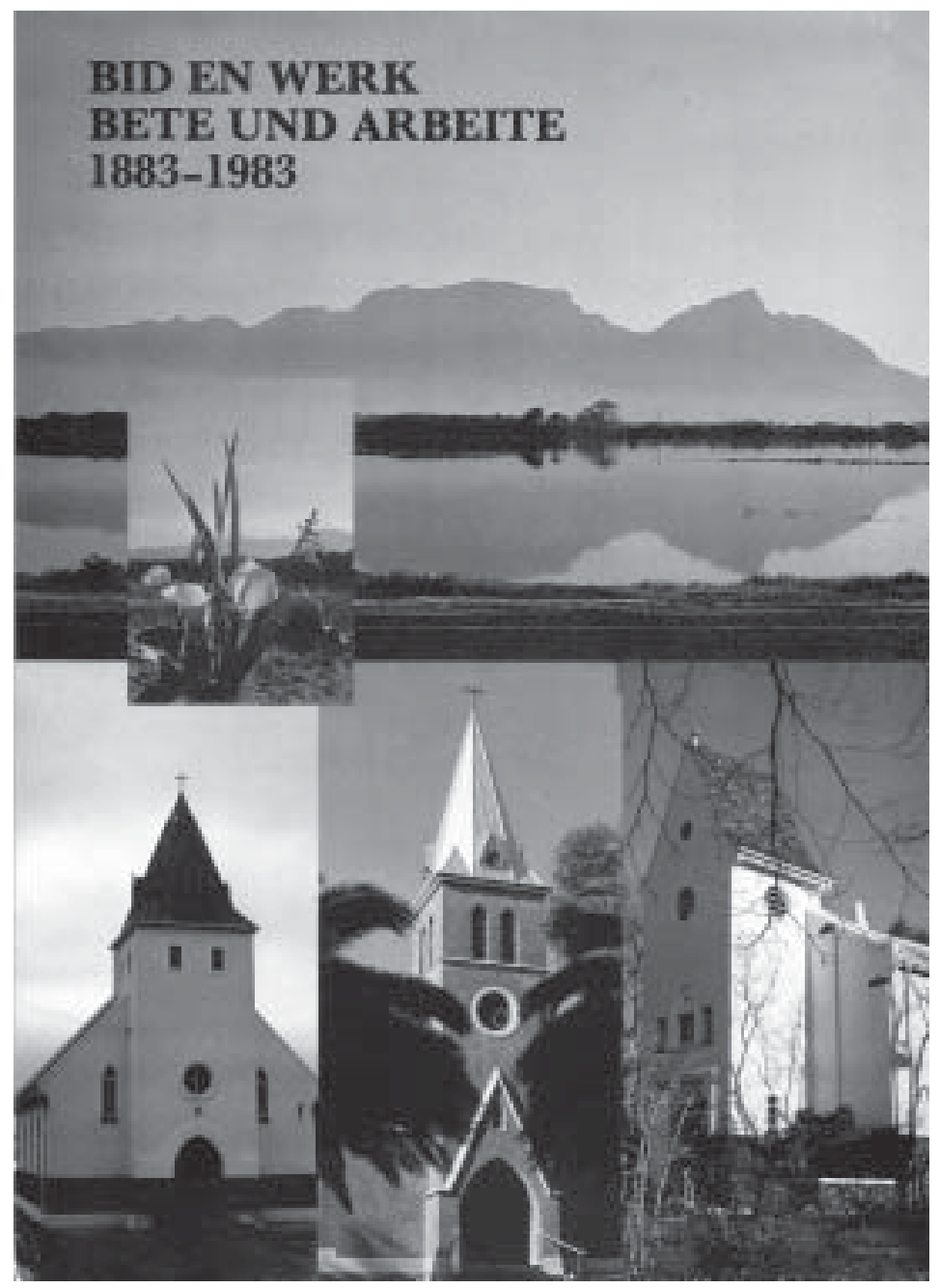

Figure 4: The cover page of a 1983 publication commemorating the arrival of the last group of settlers in 1883. The three churches of the three congregations as well as the view over one of a seasonal vlei towards

Table Mountain can be seen on the cover. The churches are, from left to right, Neu-Eisleben, Philippi and Wynberg.

(L. Rabe, Bid en Werk/Bete und Arbeite 1883-1983, Lansdowne, 1983, cover page) 
they have an inverted pyramid with a mass of seniors at the top. People have literally died out, says Ruth Ellmann. ${ }^{133}$

\section{In conclusion}

It must be one of the ironies of history that the church which led to the establishment of the agricultural community consisting of three groups of immigrants, will cease to be independent in the year in which a number of commemorations will take place. The ironical fact that these two churches, which, a century ago, were embroiled in a "Streit" in terms of independence, will now be forced to work together, the one as a parish of the other within a cooperation agreement, can also not be disregarded.

Although there are many other members in the two churches today who are not descendants of the original German immigrants, especially in the Wynberg congregation, there must be some of the elders, who, had they still been alive and aware of this development, would have said that which must be together, has come together again.

At a much remembered Golden Jubilee celebration in 1933, organised by the Philippi congregation, but in which all the Lutheran congregations took part, and where the mutual greeting was "50 Years of hard manual labour" ("50 Jahre harte Hände-Arbeit"), ${ }^{134}$ this Biblical quotation was regarded as the motto of the day: "Hold on to what you have, so that no one take the crown from you" ("Halte was du hast, dass niemand deine Krone nehmet"). ${ }^{135}$

At the time, the "Krone" was interpreted as the community's language, school and church. Although nowadays German is spoken by the older generation only, and no schools exist anymore, almost eight decades later, one can say that the community is still holding on to what is theirs, and, once again, is standing together in an attempt to ensure the future existence of that which is part of their culture and their creed, namely the Lutheran church.

This "lifebuoy" to the Wynberg congregation, might, therefore, in a sense, also ensure the survival of Philippi, the last of the three congregations, for the descendants of the German immigrants to the Philippi Flats.

\footnotetext{
133 Interview: Ruth Ellmann, born Hörstmann, Philippi, 2007-01-08.

134 Interview: Idi Bode, born Schultz, and Fidi Schultz, 1992.

135 L. Rabe, 'n Kultuurhistoriese studie van die Duitse nedersetting Philippi op die Kaapse Vlakte, p. 512.
} 